\title{
Extraction and Quantification of Carpaine from Carica papaya Leaves of Vietnam
}

\author{
Do Thi Hoa Vien ${ }^{1}$, Tran Van Loc ${ }^{2}$ \\ ${ }^{1}$ School of Biotechnology and Food Technology, Hanoi University of Science and Technology, Hanoi, Vietnam \\ ${ }^{2}$ Institute of Chemistry, Vietnam Academy of Science and Technology, Hanoi, Vietnam
}

\begin{abstract}
Our previous research indicated that carpaine and its derivative pseudocarpaine extracted from Carica papaya leaves had anti-cancer activity. In this study, we extracted the total alkaloid from Carica papaya leaves, then extracted carpaine and quantitative analyzed carpaine in the total alkaloid. Carica papaya leaves was crushed, and then extracted with EtOH to obtain the total extract. This extract was extracted with suitable solvent to obtain total alkaloid. Continued to extract the total alkaloid by using open column chromatography and crystallizing method to purify carpaine. The research result showed that the total alkaloid in Carica papaya leaves was $0.2 \%$ comparing with dried material. Quantitative analyze of purified carpaine by HPLC determined that carpaine was the main alkaloid with the content was $63 \%$ of the total alkaloid extracted from Carica papaya leaves.
\end{abstract}

Keywords-Alkaloid, Carica papaya leaves, carpaine, extract, purify, quantitative analyze.

\section{INTRODUCTION}

Carica papaya (CP) leaves have been used as folk remedies to treat cancer in Australia, Brazil and Vietnam (H.W. Tietze, 1997). It is widely believed that Carica papaya $\mathrm{L}$. (papayaceae family) originated from Central America, and then widely planted in tropical and subtropical countries. The major components in papaya plants have been known to consist of papain and chymopapain - two important proteolysis enzymes, carotenoids, alkaloids, monoterpenoids, flavonoids, glucosinolates, minerals, vitamins, etc... The distribution of these components is dependent on the parts of tree (A.U. Ogan, 1971; A. Canidi, 2007; Do Tat Loi, 1999; Do Huy Bich, 2004).

$\mathrm{CP}$ leaves have been known as the by-products of the process of harvesting $\mathrm{CP}$ fruits. The use of papaya leaves as a folk medicine has been reported in several countries. For instance, aqueous extract of CP leaves have been used as a folk medicine to support in cancer treatment process in Vietnam for a long time ago. Similarly, aboriginal inhabitants of Gold Cost-Queensland in Australia also used papaya leaves (paw paw leaves) as folk remedy to treat lung cancer since 1962 (H. Clark, 2010). A recent study by Otsuki et al. found that the fraction of papaya leaves extract with molecular weight less than 1,000 might inhibit the tumor cell growth on the 10 tested tumor cell lines and mediated Th1-type cytokines in human immune system. Interestingly, it has been found that aqueous papaya leaves extract is relatively safe to normal cells. Therefore, the use of papaya leaves extract in cancer treatment may help to avoid the unexpected effects for patients compared to other common therapeutics $(N$. Otsuki et al., 2010).

Our previous research indicated that the total alkaloid, carpaine and pseudocarpaine extracted from Carica papaya leaves had toxic activity on four tested cancer cell lines: carcinoma cell $\mathrm{KB}$, lung cancer cell LU-1, breast cancer cell MCF7 and leukemia cell HL-60 (Do Thi Hoa Vien et al., 2013; Ho Thi Ha, 2014). Among them, carpaine showed the most powerful toxicity toward four of above cancer cell lines with $\mathrm{IC}_{50}$ from 1.13 to 2.94 $\mu \mathrm{g} / \mathrm{ml}$ (Ho Thi Ha, 2014).

This study extracted the total alkaloid and carpaine from papaya leaves. Therefore, quantified the carpaine in obtained total alkaloid to apply carpaine as well as total alkaloid from papaya leaves as anti-cancer therapy.

\section{MATERIALS AND METHODS}

Carica papaya leaves was collected at Dong Anh district - Hanoi, cleaned, dried at $50^{\circ} \mathrm{C}$ to humidity $7.5-9.5 \%$, and then crushed to the size of $1 \mathrm{~mm}$.

Crushed CP leaves was extracted by EtOH to obtain the total extract. Then used the suitable solvent to extract the total alkaloid.

Continued to extract the total alkaloid by using silica gel open column chromatography, solvent system of $\mathrm{CH}_{2} \mathrm{Cl}_{2} / \mathrm{MeOH}$ (with $\mathrm{MeOH}$ gradient from 0 to $20 \%$ ), we obtained 5 fractions. Then, extracted third fraction as above (with $\mathrm{CH}_{2} \mathrm{Cl}_{2} / \mathrm{MeOH}=95: 5$ ), we obtained $\mathrm{CP} 2$. Crystallized $\mathrm{CP} 2$ with $\mathrm{CH}_{2} \mathrm{Cl}_{2} /$ n-hexane (rate 3:1), we obtain purified compound CP-pur. Evaporated the solvent using Rotavapor Buchi R-114 at $45-50^{\circ} \mathrm{C}$.

Used MS and NMR method $\left({ }^{1} \mathrm{H}-\mathrm{NMR},{ }^{13} \mathrm{C}-\mathrm{NMR}\right.$, COSY, DEPT) to determine the mass and the structure of CP-pur. 
Quantitative analyzed of carpaine using LC/MS method with Alliance series 2695; detector PDA 2996 of Waters Company; column: Sunfire -C18 RP (4.6 x $150 \mathrm{~mm})$, $5 \mu \mathrm{m}$.

\section{RESULTS}

\subsection{Extract of CP-pur compound from total alkaloid}

Carica papaya leaves was crushed, and then extracted with EtOH to obtain the total extract. This extract was extracted with $\mathrm{CH}_{2} \mathrm{Cl}_{2}$ at acidic and alkaline condition to obtain total alkaloid.

Continued to extract $500 \mathrm{mg}$ total alkaloid by using open column chromatography (OCC): absorbent was silica gel (Merck, size: $0.40-0.63 \mathrm{~mm}$ ), solvent system was $\mathrm{CH}_{2} \mathrm{Cl}_{2} / \mathrm{MeOH}$ (with $\mathrm{MeOH}$ gradient from 0 to $20 \%$ ). Qualitatively analyzed extracted fractions by thin layer chromatography (TLC): silica gel thin layer (Merck, $60 \mathrm{GF}_{254}$, thick: $0.2 \mathrm{~mm}$ ), using Dragendorff reagent to detect alkaloids. Based on the result of TLC qualitative analyze, we group to 5 main fractions F1, F2, F3, F4 and F5 with the mass was $20 \mathrm{mg}, 60 \mathrm{mg}, 260 \mathrm{mg}, 50 \mathrm{mg}$ and $25 \mathrm{mg}$, respectively. Then, the third fraction F3 with the most of mass $(260 \mathrm{mg}$ ) was selected to continue to also extract by silica gel open column chromatography (with $\left.\mathrm{CH}_{2} \mathrm{Cl}_{2} / \mathrm{MeOH}=95: 5\right)$, we obtained 190mg CP2. Crystallized $190 \mathrm{mg} \mathrm{CP} 2$ with $\mathrm{CH}_{2} \mathrm{Cl}_{2} /$ n-hexane (rate $3: 1$ ) to obtain purified compound CP-pur with the mass of $150 \mathrm{mg}$. This process is showed in Fig. 1.

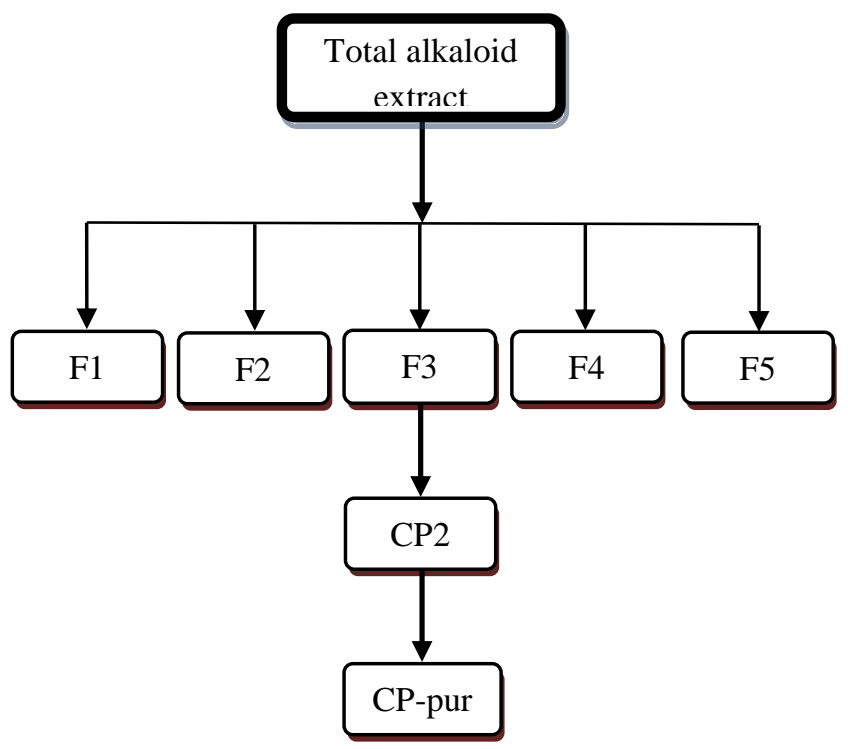

Fig. 1: The extracted and purified process of CP-pur

\subsection{Determination of structure of CP-pur compound} ESI-MS spectre of CP-pur: positive ion; $m / z 479[\mathrm{M}+\mathrm{H}]^{+}$ (Fig. 2)

${ }^{1} \mathrm{H}-\mathrm{NMR}$ spectre of CP-pur (Fig. 3) showed the signals of 2 group of methyl doublet bond with carbon of 3rd grade
$\left(-\mathrm{CH}_{3}\right)$ at $\delta_{\mathrm{H}} 1.16 \mathrm{ppm}\left(6 \mathrm{H}, \mathrm{d}, \mathrm{J}=6.5 \mathrm{~Hz}, \mathrm{H}-15, \mathrm{H}-15^{\prime}\right)$. The resonant signals of 2 protons were showed at $\delta_{\mathrm{H}} 4.89$ ppm (2H, br, s, H-12 and H-12') in the low magnetic area.

Desplay lieport - Selected Window Sodectod Analysis

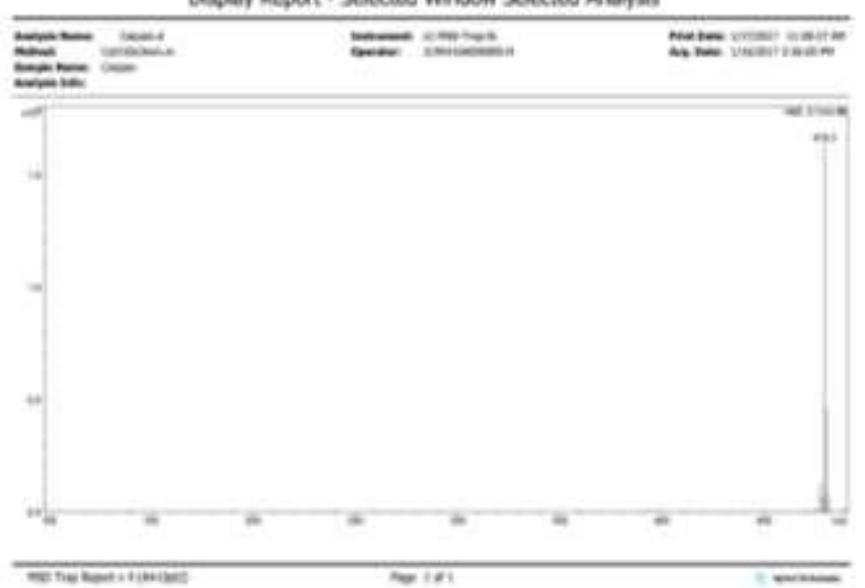

Fig. 2: ESI-MS spectre of CP-pur

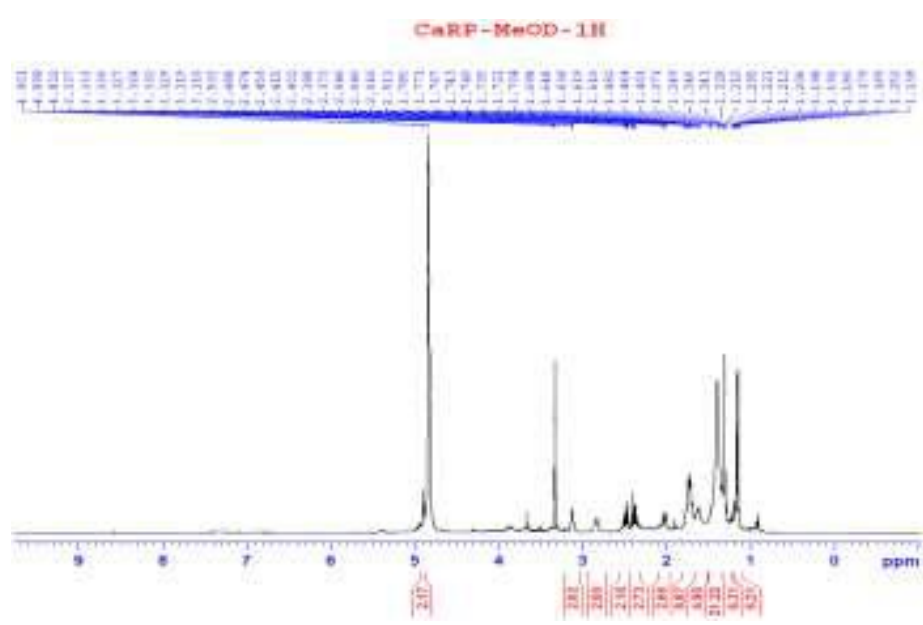

Fig. 3: ${ }^{1} H$-NMR spectra of CP-pur

${ }^{13} \mathrm{C}$-NMR spectre (Fig.4) showed resonant signals of 14 carbons with 1 carbon of 4 th grade at $\delta_{c} 174.8 \mathrm{ppm}$ of ester group; 3 carbons of 3 rd grade at $\delta_{c}$ 55.0, 57.6 and 70.9 ppm; 9 carbons of 2nd grade and 1 group of methyl at $\delta_{\mathrm{c}} 17.4 \mathrm{ppm}$.
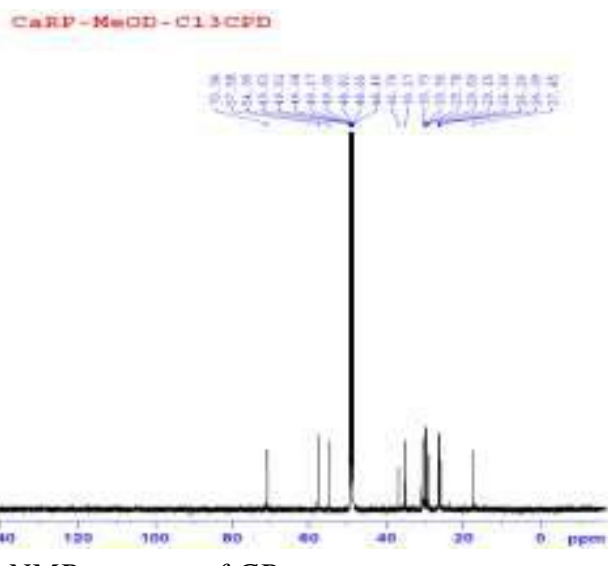

Fig.4: ${ }^{13}$ C-NMR spectra of CP-pur 
Based on the data of MS and NMR spectra, and compared with reference (Tasqiah Julianti, 2014; Taro Sato et al., 2003), we determined that CP-pur was an alkaloid with symmetric structure and it was carpaine. The spectra data NMR of CP-pur isolated from Carica papaya leaves and of published carpaine in reference (Tasqiah Julianti, 2014) were described as in Table 1.

The chemical structure of carpaine was described in Fig. 5.

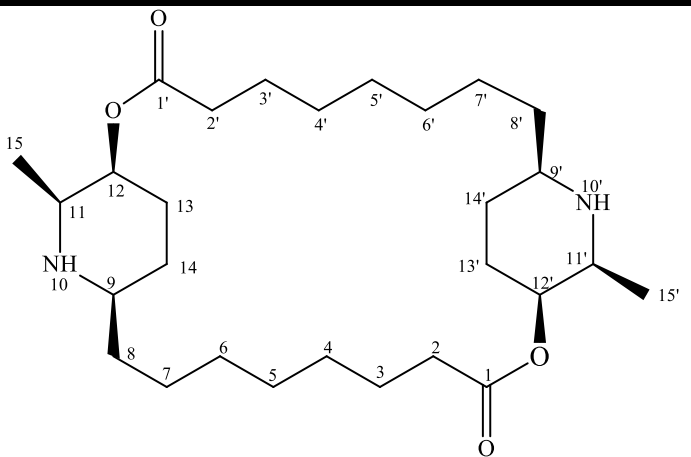

Fig. 5: Chemical structure of carpaine

Table 1: The NMR data of CP-pur and of carpaine

\begin{tabular}{|c|c|c|c|c|c|}
\hline \multirow{2}{*}{\multicolumn{2}{|c|}{ Location and groups }} & \multicolumn{2}{|c|}{$\mathrm{CP}-\operatorname{pur}\left(\mathrm{CD}_{3} \mathrm{OD}\right)$} & \multicolumn{2}{|c|}{ Published carpaine $\left(\mathrm{CDCl}_{3}\right)$} \\
\hline & & $\delta_{\mathrm{H}}(\mathrm{J}=\mathrm{Hz})$ & $\delta_{\mathrm{C}}$ & $\delta_{\mathrm{H}}(\mathrm{J}=\mathrm{Hz})$ & $\delta_{C}$ \\
\hline 1 & $\mathrm{C}=\mathrm{O}$ & - & 174.8 & - & 172.8 \\
\hline 2,2 & $\mathrm{CH}_{2}$ & $2.36-2.51(4 \mathrm{H}, \mathrm{m})$ & 35.2 & $2.34-2.50(4 \mathrm{H}, \mathrm{m})$ & 32.8 \\
\hline $3,3^{\prime}$ & $\mathrm{CH}_{2}$ & $1.60-1.70(4 \mathrm{H}, \mathrm{m})$ & 26.2 & $1.40-1.72(4 \mathrm{H}, \mathrm{m})$ & 23.3 \\
\hline $4,4^{\prime}$ & $\mathrm{CH}_{2}$ & $1.29-1.43(4 \mathrm{H}, \mathrm{m})$ & 29.6 & $1.16-1.42(4 \mathrm{H}, \mathrm{m})$ & 27.7 \\
\hline 5,5 & $\mathrm{CH}_{2}$ & $1.29-1.43(4 \mathrm{H}, \mathrm{m})$ & 29.8 & $1.16-1.42(4 \mathrm{H}, \mathrm{m})$ & 27.8 \\
\hline $6,6 ?$ & $\mathrm{CH}_{2}$ & $1.29-1.43(4 \mathrm{H}, \mathrm{m})$ & 30.6 & $1.16-1.42(4 \mathrm{H}, \mathrm{m})$ & 28.2 \\
\hline $7,7^{\prime}$ & $\mathrm{CH}_{2}$ & $1.29-1.43(4 \mathrm{H}, \mathrm{m})$ & 26.1 & $1.16-1.42(4 \mathrm{H}, \mathrm{m})$ & 23.1 \\
\hline $8,8^{\prime}$ & $\mathrm{CH}_{2}$ & $1.60-1, .70(4 \mathrm{H}, \mathrm{m})$ & 36.8 & $1.40-1.72(4 \mathrm{H}, \mathrm{m})$ & 24.1 \\
\hline $9,9^{\prime}$ & $\mathrm{CH}$ & $2.81-2.85(2 \mathrm{H}, \mathrm{m})$ & 57.6 & $2.75-2.80(2 \mathrm{H}, \mathrm{m})$ & 56.6 \\
\hline $10,10^{\prime}$ & $\mathrm{NH}$ & - & - & - & \\
\hline $11,11^{\prime}$ & $\mathrm{CH}$ & $3.10-3.14(2 \mathrm{H}, \mathrm{m})$ & 55.0 & $3.06-3.11(2 \mathrm{H}, \mathrm{m})$ & 53.8 \\
\hline $12,12^{\prime}$ & $\mathrm{CH}$ & $4.89(2 \mathrm{H}, \mathrm{br}, \mathrm{s})$ & 70.9 & $4.84(2 \mathrm{H}, \mathrm{br}, \mathrm{s})$ & 68.1 \\
\hline $13,13^{\prime}$ & $\mathrm{CH}_{2}$ & $2.05-2.10(2 \mathrm{H}, \mathrm{m})$ & 29.2 & $1.92-1.98(2 \mathrm{H}, \mathrm{m})$ & 26.6 \\
\hline $14,14^{\prime}$ & $\mathrm{CH}_{2}$ & $1.29-1.43(4 \mathrm{H}, \mathrm{m})$ & 26.5 & $1.16-1.42(4 \mathrm{H}, \mathrm{m})$ & 25.2 \\
\hline 15,15 & $\mathrm{CH}_{3}$ & $1.16(6 \mathrm{H}, \mathrm{d}, \mathrm{J}=6,5 \mathrm{~Hz})$ & 17.4 & $1.09(6 \mathrm{H}, \mathrm{d}, \mathrm{J}=6,4 \mathrm{~Hz})$ & 15.8 \\
\hline
\end{tabular}

Carpaine was isolated from papaya leaves in 1962 (Tichý M. et al., 1962). Carpaine also was separated from the leaf, fruit and root of papaya (Singh I.D, 1978; Pedro Chávez - Quintal et al., 2011). In Vietnam, carpaine also extracted from papaya leaves by Nguyen Tuong Van et al. (Nguyen Tuong Van et al., 1983) and by Ho Thi Ha (Ho Thi $\mathrm{Ha}$, 2014). However, not yet have publication about the content of carpaine in papaya leaf and also in other extract from papaya.

\subsection{Quantitative analyse of carpaine}

\subsubsection{Etablish of standard curve}

Prepared original solution of carpaine in $\mathrm{MeOH}$ with the concentration of $1 \mathrm{mg} / \mathrm{ml}$. Diluted the original solution to the solutions with concentration of $0.1,0.2,0.5$ and 0.7 $\mathrm{mg} / \mathrm{ml}$. Then, loaded the aboves solution by LC/MS: mobile phase was acetonitrile and formic acid $0.1 \%$; flowing speed was $1 \mathrm{ml} / \mathrm{min}$; detector PDA at $205 \mathrm{~nm}$. Gradient loading was presented as in Table 2.
Table 2: LC/MS gradient loading

\begin{tabular}{|c|c|c|}
\hline $\begin{array}{c}\text { Time } \\
(\min )\end{array}$ & $\begin{array}{c}\text { Formic acid } \\
0.1 \%(\%)\end{array}$ & $\begin{array}{c}\text { Acetonitrile } \\
(\%)\end{array}$ \\
\hline $0-2$ & 80 & 20 \\
\hline $2-20$ & 0 & 100 \\
\hline $20-30$ & 0 & 100 \\
\hline $30-35$ & 80 & 20 \\
\hline
\end{tabular}

The results of HPLC loading were following as in Table 3 .

Table 3: The results of $L C / M S$

\begin{tabular}{|c|c|c|c|}
\hline $\begin{array}{c}\text { Concentration } \\
(\mathrm{mg} / \mathrm{ml})\end{array}$ & $\begin{array}{c}\text { Peak } \\
\text { intensity }\end{array}$ & $\begin{array}{c}\text { Peak intensity } \\
\text { LT }\end{array}$ & $\begin{array}{c}\text { RT } \\
(\mathrm{min})\end{array}$ \\
\hline 0.1 & 5943201 & 9337168 & 17.8 \\
\hline 0.2 & 16854336 & 15043641 & 17.8 \\
\hline 0.5 & 37818224 & 32163058 & 17.8 \\
\hline 0.7 & 39504112 & 43576003 & 17.8 \\
\hline
\end{tabular}


Followed the results in Table 3 to establish standard curve as in Fig.6.

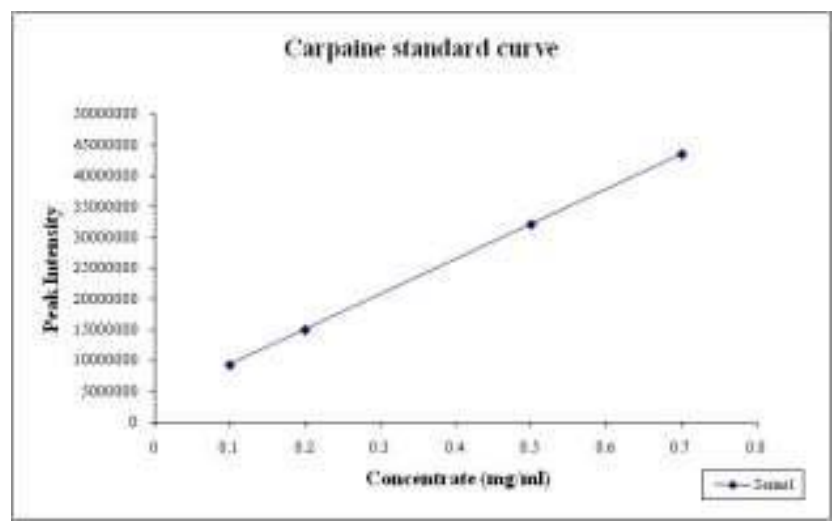

Fig. 6: Carpaine standard curve

\subsubsection{Quantitative analyze of carpaine}

Carried out the HPLC analyze of total alkaloid extract in the same conditions of standard curve establish. Then, quantitatively analyzed carpaine in the total alkaloid extract basing on standard curve of carpaine, we obtained the result in Table 4.

Table 4: The content of carpaine in the total alkaloid

\begin{tabular}{|c|c|c|c|}
\hline $\begin{array}{c}\text { Total alkaloid } \\
\text { extract }(\mathrm{mg})\end{array}$ & $\begin{array}{c}\text { Peak } \\
\text { intensity }\end{array}$ & $\begin{array}{c}\text { Carpaine } \\
(\mathrm{mg})\end{array}$ & $\begin{array}{c}\text { Carpaine }(\% \\
\text { in total } \\
\text { alkaloid } \\
\text { extract) }\end{array}$ \\
\hline 1 & $4 \mathrm{E}+07$ & 0.63 & 63 \\
\hline
\end{tabular}

The result on table 3 indicated that the content of carpaine in the total alkaloid extract was $63 \%$.

\section{CONCLUSION}

Used two times of silica gel open column chromatography (OCC) with gradient solvent system $\mathrm{CH}_{2} \mathrm{Cl}_{2} / \mathrm{MeOH}$, then crystallized with $\mathrm{CH}_{2} \mathrm{Cl}_{2} / \mathrm{n}$-hexane, we obtain carpaine from total alkaloid. The content of carpaine was $63 \%$ comparing with the total alkaloid extracting from Carica papaya leaves.

\section{ACKNOWLEDGEMENTS}

The authors would like to thank the Vietnamese Ministry of Industry and Trade (Program of Pharmaceutical Chemistry) for the financial support for this study by the CNHD.ĐT.065/15-17 project.

\section{REFERENCES}

[1] H.W. Tietze (1997). Papaya the Medicine Tree. Bermagui South-Harald W. Tietze Pub...
[2] A.U. Ogan (1971). The basic constituents of the leaves of Carica papaya. Phytochemistry 10(10), 2544-2547.

[3] A. Canini (2007). Gas chromatography mass spectrometry analysis of phenolic compounds from Carica papaya L. leaves. J. of Food Composition and Analysis 20(7), 584-590.

[4] Do Tat Loi (1999). Vietnamese medicine. Medicinal editor, Hanoi - Vietnam.

[5] Do Huy Bich (2004). Medicinal herb and animal in Vietnam. Vol. 1 and 2, Editor of Science and Technique, Hanoi 2004.

[6] H. Clark (2010). Papaya leaves, the anti-cancer treatment. Cancer therapies, from: http://www.huldaclarkzappers.com/?page_id=134.

[7] N. Otsuki, N.H. Dang, E. Kumagai, A. Kondoc, S. Iwataa, C. Morimotoa (2010). Aqueous extract of Carica papaya leaves exhibits anti-tumor activity and immunomodulatory effects. Journal of Ethno pharmacology 127 (3), 760-767.

[8] Do Thi Hoa Vien, Do Thi Thao (2013). Preliminary findings on anticancer and lymphocyte stimulated activities of bioactive compounds extracted from Vietnam Carica papaya leaves. Journal of Food Science and Engineering 3, 447-452.

[9] Ho Thi Ha (2014). Research on biological activity of the compounds extracted from Carica papaya leaves. Thesis of Doctor Philosophy, Hanoi University of Science and Technology, Hanoi, Vietnam.

[10] Singh I.D. (1978). Papaya. Oxford and IBH publishing co. PVT.LTD, New Delhi Bombay, Calcutta.

[11] Tasqiah Julianti (2014). Discovery of natural antiprotozoals from medicinal plants Saussure Costus and Carica papaya. Thesis of Doctor Philosophy, University of Basel, Switzerland, 41-48.

[12] Taro Sato, Sakae Aoyagi, Chihiro, Kibayashi (2003). Enantionselective total synthesis of (+)-Azimine and (+)-Carpaine. Org. Lett., 5(21), 3839-3842.

[13]Pedro Chávez - Quintal, Tania González - Flores, Ingrid Rodríguez - Buenfil, Santiago Gallegos Tintoré (2011). Antifungal activity in ethanolic extracts of Carica papaya L. cv. Maradol leaves and seeds. Indian J Microbial, 51(1), 54-60.

[14] Tichý M. and Sicher J. (1962). The configuration of carpaine. Tetrahedron letters, No. 12, 511-514. 